\title{
Keprakan dalam Pertunjukan Wayang Gaya Yogyakarta: Studi Kasus Pementasan Ki Hadi Sugito
}

\author{
Ign. Nuryanta Putra ${ }^{1}$, Hanggar B. Prasetya, dan Sunyata
}

Fakultas Seni Pertunjukan, Institut Seni Indonesia Yogyakarta

\begin{abstract}
Keprakan adalah bunyi yang dihasilkan oleh cempala tangan atau cempala kaki yang dipukulkan pada kotak wayang dalam pertunjukan wayang. Keprakan menjadi bagian dari karawitan pedalangan dan memiliki peran penting dalam membangun estetika pertunjukan. Penelitian ini bertujuan untuk mendeskripsikan dan memahami teknik dan pola keprakan dalam pertunjukan wayang. Data diperoleh melalui pengamatan pada dua puluh pertunjukan wayang yang dipergelarkan oleh Ki Hadi Sugito. Analisis musikal dilakukan dengan cara melihat hubungan antara keprakan dengan jenis gending dan suasana adegan yang diciptakan. Berdasarkan hasil penelitian dapat disimpulkan bahwa bunyi keprak memiliki dua fungsi utama, yaitu sebagai penanda atau aba-aba dari dalang kepada para pengrawit dan memberikan suasana dramatik sehingga pertunjukan terasa hidup. Pola keprakan terbentuk dari dua unsur yaitu neteg dan mlatuk. Dari dua pola ini berkembang pola permainan lainnya seperti mbanyu tumetes, ngeceg, nisir, nduduk, dan geter.
\end{abstract}

Kata kunci: keprakan, dhodhogan, estetika wayang, Hadi Sugito, karawitan

\begin{abstract}
ABSTRAK
Keprakan in Yogyakarta Wayang Style: A Case Study on Ki Hadi Sugito's Wayang Performance. Keprakan is the sound produced by hand or foot cempala slapped on the puppets box in a wayang performance. Keprakan becomes part of the music for wayang and has an important role in building a performing aesthetic. This study aims to describe and understand the keprakan techniques and patterns in wayang performance. The data are obtained through observations on twenty of Ki Hadi Sugito's wayang performances. The musical analysis is done by looking at the relationship between keprakan with the musical types and the created atmosphere scene. Based on this study, it can be concluded that the keprak sound has two main functions, namely as signs or clues from the puppet master to the musicians, and to provide a dramatic atmosphere. Keprakan pattern is formed of two elements, namely neteg and mlatuk. Of these two patterns produce other patterns such as mbanyu tumetes, ngeceg, nisir, nduduk, and geter.
\end{abstract}

Keywords: keprakan, dhodhogan, wayang aesthetic, Hadi Sugito, gamelan for wayang

\section{Pendahuluan}

Penelitian ini mengkaji keprakan dalam pertunjukan wayang yang dipergelarkan oleh Ki Hadi Sugito. Dalam tradisi pedalangan gaya Yogyakarta, keprakan adalah bunyi yang dihasilkan dari cempala tangan atau cempala kaki yang dipukulkan ke dalam kotak wayang atau pada kecrek yaitu plat logam bernada ji (1) yang digantungkan pada kotak wayang yang dilakukan oleh dalang dalam pertunjukan wayang. Keprakan memiliki dua fungsi utama yaitu sebagai tanda atau abaaba yang diberikan dalang kepada para pengrawit dan untuk menghasilkan efek estetika bunyi dalam pertunjukan wayang.

Dalam pedalangan gaya Surakarta dibedakan antara keprakan dan dhodhogan. Keprakan dihasilkan oleh bunyi keprak, yaitu susunan empat plat logam masing-masing bernada 6, 2, 3, dan 1 yang digantungkan pada kotak wayang, sedangkan

\footnotetext{
Alamat korespondensi: Prodi Seni Pedalangan, ISI Yogyakarta. Jln. Parangtritis km 6,5 Sewon, Bantul, Yogyakarta. Hp: 087834866721. Email: kinuryanto@yahoo.com
} 
dhodhogan dihasilkan ketika cempala tangan dipukulkan pada kotak wayang. Keprakan biasanya dilakukan oleh dalang dengan cara menjejakkan kaki kanannya.

Keprakan dan dhodhogan memiliki fungsi yang sama dan saling menggantikan. Yang membedakan adalah cara menghasilkan bunyi. Ketika tangan kiri dalang tidak sedang memegang wayang, tangan kiri memegang cempala tangan untuk menghasilkan dhodhogan. Saat kedua tangan dalang menggerakkan wayang, tangan kiri dalang tidak memungkinkan memegang cempala, maka tugas dhodhogan digantikan oleh keprakan yang dihasilkan oleh cempala kaki dengan kecrek (keprak). Dalam pedalangan gaya Yogyakarta tidak dibedakan antara keprakan dan dhodhogan, keduanya dinamakan keprakan.

Keprakan atau dhodhogan merupakan salah satu dari lima unsur karawitan pedalangan yang lain yang meliputi suluk, tembang, kombangan, dhodhogan, dan keprakan (Soetarno, 2005: 86). Menurut Mudjanattistama, dkk (1977: 16) fungsi keprakan adalah untuk memulai dan memberhentikan atau nyuwuk gending. Berdasarkan pengamatan di lapangan dan pengalaman peneliti sebagai dalang dapat diketahui bahwa keprakan tidak hanya berfungsi seperti yang disampaikan Mudjanattistama di atas, akan tetapi juga untuk menuntun tempo pertunjukan sehingga terbentuk rasa dan estetika pedalangan yang diinginkan. Bunyi keprak sangat menentukan estetika pertunjukan. Dengan demikian aspek ini sangat diperlukan dalam pertunjukan wayang.

Cara memberi keprakan setiap jenis gending berbeda. Pada pertunjukan wayang terdapat lima jenis gending yang biasa digunakan yaitu sampak, playon, ayak-ayak, ketawang, ladrang, dan Gendhing Candra. Selain itu juga dijumpai perbedaan keprakan untuk memberhentikan atau nyuwuk gending pada jejer tokoh alus dengan tokoh gagahan. Pertanyaan yang diajukan adalah: (1) Bagaimana keprakan untuk memulai berbagai jenis gending; (2) Bagaimana keprakan untuk berbagai nyuwuk pada berbagai gending?; (3) Apa fungsi keprakan dalam pertunjukan wayang?; dan (4) Mengapa keprakan mampu menghasilkan estetika pedalangan?
Penelitian ini membahas keprakan dalam pementasan wayang yang dipergelarkan oleh Ki Hadi Sugito. Pementasan Ki Hadi Sugito dipilih sebagai studi kasus karena pementasannya disukai banyak orang dan menjadi patron bagi dalang-dalang gaya Yogyakarta lainnya. Hingga saat ini belum ada dalang yang kepopuleran dan produktifitasnya menyamai beliau. Terdapat ratusan pita casset pertunjukan wayang yang dihasilkan selama beliau masih hidup (Prasetya, 2011: 3). Walaupun dia telah meninggal, suaranya masih diperdengarkan hampir setiap malam di radio radio di wilayah Yogyakarta dan sekitarnya melalui ratusan pita kaset rekaman yang ditinggalkan.

Walau keprakan merupakan unsur yang sangat penting dalam pertunjukan wayang, namun hingga saat ini para peneliti dan praktisi belum ada yang membahas atau memperbincangkannya. Untuk itulah penelitian ini masih relevan dilakukan.

\section{Jenis Keprakan}

Ada tujuh jenis keprakan yaitu neteg, mlatuk, banyu tumetes, geter, nduduk, nisir, dan ngeceg. Tujuh jenis keprakan ini sebenarnya tersusun oleh kombinasi dari neteg dan mlatuk.

1. Nêtêg

Keprakan ini dihasilkan ketika cêmpala dipukulkan pada kotak satu kali sehingga dihasilkan bunyi dhog. Keprakan ini biasanya digunakan untuk aba-aba ketika dalang menghendaki lagon. Selain itu juga digunakan untuk mempertegas dramatik pada pocapan (dialog) wayang.

\section{Mlatuk}

Keprakan Mlatuk dihasilkan ketika cêmpala dipukulkan kotak dua kali secara cepat. Pukulan pertama lemah, sedangkan pukulan kedua agak keras sehingga bunyi yang dihasilkan dhegdhog atau dhêrog. Keprakan ini biasanya digunakan untuk mengatur tempo gending.

3. Gêtêr

Keprakan Gêtêr dihasilkan ketika cêmpala dipukulkan kotak secara berulang dengan tempo yang cepat seperti getaran sehingga bunyi yang dihasilkan terdengar dhog dhog dhog dhog dhog dhog dhog dhog dhog dhog dhog. Keprakan ini 
biasanya digunakan untuk mengiringi suluk ada$a d a$ atau narasi yang menggambarkan suasana tegang seperti disampaikan Mudjanattistomo (1977: 16) berikut:

Sadaya ada-ada tuwin kawin mawi dipun sarengi keprakan geter, sasampunipun lajeng mlatuk sepisan neteg kaping kalih. Keprakan geter mengku pikajeng kangge narik raos, mila kedah jumbuh lan kawontenan. Sadaya carita ingkang mengku raos pakewet utawi gugup inggih mawi kasarengan keprakan geter; dene antal seseging keprakan kedah kajumbuhaken kaliyan kawontenan.

(Semua jenis lagu ada-ada dan kawin diikuti keprakan geter, setelahnya diikuti mlatuk satu kali dan neteg dua kali. Keprakan geter dimaksudkan untuk membangkitkan rasa sesuai yang diinginkan. Semua cerita yang memiliki rasa tergesa-gesa dan menakutkan diikuti oleh keprakan geter, sementara tingkat tempo disesuaikan keadaan)
Keprakan geter juga digunakan untuk mengiringi $k a n d h a$ atau penarasian adegan gara-gara.

4. Mbanyu tumètès

Keprakan Mbanyu tumètès dihasilkan ketika cêmpala dipukulkan kotak secara berulang dengan tempo yang lambat. Keprakan ini seperti gêtêr namun iramanya lambat seperti tempo air yang menetes. Bunyi yang dihasilkan adalah dhog - dhog - dhog - dhog - dhog - dhog - dhog. Keprakan seperti ini biasanya digunakan untuk pertanda sirep (gamelan sayup-sayup) atau akan berhenti (suwuk). Fungsi keprakan ini adalah mengatur tempo gending.

\section{Nduduk}

Keprakan Nduduk dihasilkan dengan cara memukulkan cempala ke dalam kotak dengan memadukan bunyi mlatuk satu kali diikuti neteg berkali-kali dengan tempo melambat diikuti jeda sebentar lalu neneg satu kali. Bunyi yang dihasilkan adalah dhêrog dhog dhog dhog dhong ....dhog. Keprakan ini biasanya digunakan untuk mengiringi wayang keluar dan masuk dalam

Tabel 1. Jenis-jenis keprakan

\begin{tabular}{|c|c|c|c|c|}
\hline No & $\begin{array}{l}\text { Jenis } \\
\text { keprakan }\end{array}$ & $\begin{array}{l}\text { Unsur } \\
\text { pembentuk }\end{array}$ & Simbol & Bunyi \\
\hline 1. & Neteg & neteg & 。 & dhog \\
\hline 2. & Mlatuk & mlatuk & $\overline{0}$. & Dhêgdhog \\
\hline 3. & $\begin{array}{l}\text { Mbanyu } \\
\text { tumetes }\end{array}$ & neteg & $\circ .0$ & $\begin{array}{l}\text { Dhog..dhog...dhog, } \\
\text { dst. }\end{array}$ \\
\hline 4 & Geter & neteg & 0000000 & Dhog.dhog.dhog, dst \\
\hline 5. & Nduduk & $\begin{array}{l}\text { Mlatuk- } \\
\text { neteg }\end{array}$ & $\overline{0} 000 . \ldots$. & $\begin{array}{l}\text { Dhêgdhog-dhog- } \\
\text { dhog-dhog......dhog }\end{array}$ \\
\hline 6 & Nisir & - & $\circ \circ 0$ & Thing-thing-thing \\
\hline 7 & Ngeceg & - & 0000000 & Ceg-ceg-ceg dst \\
\hline
\end{tabular}


kelir, atau gerakan wayang saat ada di kelir. Keprakan ini juga digunakan untuk memberi tekanan pada gerak saat wayang capeng dan ulat-ulat.

6. Nisir

Keprakan Nisir dihasilkan oleh cempala kaki yang dipukulkan terus menerus pada keprak dengan tempo lebih cepat dari Mbanyu tumetes, akan tetapi lebih lambat dari geter.

\section{Ngeceg}

Keprakan ngeceg dihasilkan oleh cempala kaki yang dipukulkan terus menerus pada keprak dengan tempo sama dengan geter.

\section{Fungsi Keprakan}

Secara umum keprak memiliki dua fungsi utama, yaitu sebagai aba-aba dan sebagai pembentuk estetika rasa pertunjukan (Brinner, 2008). Kedua fungsi ini sering tidak terpisahkan dan berhubungan satu sama lain. Sering pada saat yang sama keprakan berfungsi sebagai tanda sekaligus sebagai pembentuk rasa.

\section{Keprakan sebagai Aba-aba (Tanda)}

Fungsi keprakan sebagai aba-aba berperan mewakili permintaan dalang yang ditujukan pada pengrawit untuk meminta sesuatu terkait dengan karawitan, antara lain memberi tanda kalau pertunjukan akan segera dimulai, meminta penggender agar segera me-ggrambyang karena dalang akan menyanyikan jenis suluk tertentu, meminta gending tertentu, meminta tempo gending dipercepat atau diperlambat, meminta iringan menjadi rep (sayup-sayup), dan meminta gending agar suwuk atau berhenti (Tabel 2).

Sebagai contoh, ketika pertunjukan akan segera dimulai, dalang memberi serangkaian keprakan yang dimaksudkan bagi para pengrawit agar segera menyajikan gending Ayak-ayak Slendro Nem. Dalang membunyikan serangkaian keprakan berupa ater-ater dan buka atau memulai gending. Antara ater-ater dan buka terdapat waktu jeda. Bagian ater-ater hanya murni sebagai tanda, sedangkan bagian buka selain berfungsi sebagai tanda juga berfungsi sebagai penuntun dan pembentuk tempo gending (Tabel 3).

Umumnya bagian ater-ater berupa keprakan neteg beberapa kali atau neteg beberapa kali diikuti mlatuk satu kali (Tabel 4). Jumlah keprakan antara pertunjukan satu dengan pertunjukan yang lain tidak selalu sama, tergantung pada suasana. Kalau semua pengrawit sudah terlihat

Tabel 2. Fungsi keprakan sebagai aba-aba atau tanda

\begin{tabular}{|c|c|c|}
\hline No. & Jenis Keprakan & Fungsi \\
\hline 1. & $\begin{array}{l}\text { Neteg satu kali setelah dialog wayang dalam } \\
\text { suasana susah atau sedih }\end{array}$ & $\begin{array}{l}\text { Tanda dalang meminta suluk lagon mambeng } \\
\text { atau tlutur }\end{array}$ \\
\hline 2. & $\begin{array}{l}\text { Neteg dua kali dengan volume keras diikuti } \\
\text { bunyi kendang dlang }\end{array}$ & Tanda meminta gending sampak \\
\hline 3. & $\begin{array}{l}\text { Mlatuk satu kali diikuti neteg satu kali setelah } \\
\text { dalang memberi sasmita gending }\end{array}$ & Minta disajikan gending tertentu \\
\hline 4. & $\begin{array}{l}\text { Geter diikuti mlatuk satu kali dan neteg satu kali } \\
\text { saat dalam gending }\end{array}$ & Minta agar gending sirep (sayup-sayup) \\
\hline 5. & $\begin{array}{l}\text { Mlatuk satu kali neteg dua kali pada kethuk } \\
\text { kedua }\end{array}$ & Sasmita rep gendhing \\
\hline 6. & $\begin{array}{l}\text { Neteg satu kali pada kenong kedua diikuti geter } \\
\text { sampai gong neteg tiga kali, setiap kenong neteg } \\
\text { tiga kali, diakhiri mlatuk satu kali neteg tiga kali }\end{array}$ & Suwuk gendhing \\
\hline 7. & Mlatuk sekali diikuti geter & Minta gending playon \\
\hline
\end{tabular}

Sumber: Pengamatan terhadap 20 pertunjukan wayang (Putra, dkk. 2013) 
Tabel 3. Keprakan untuk memulai pertunjukan

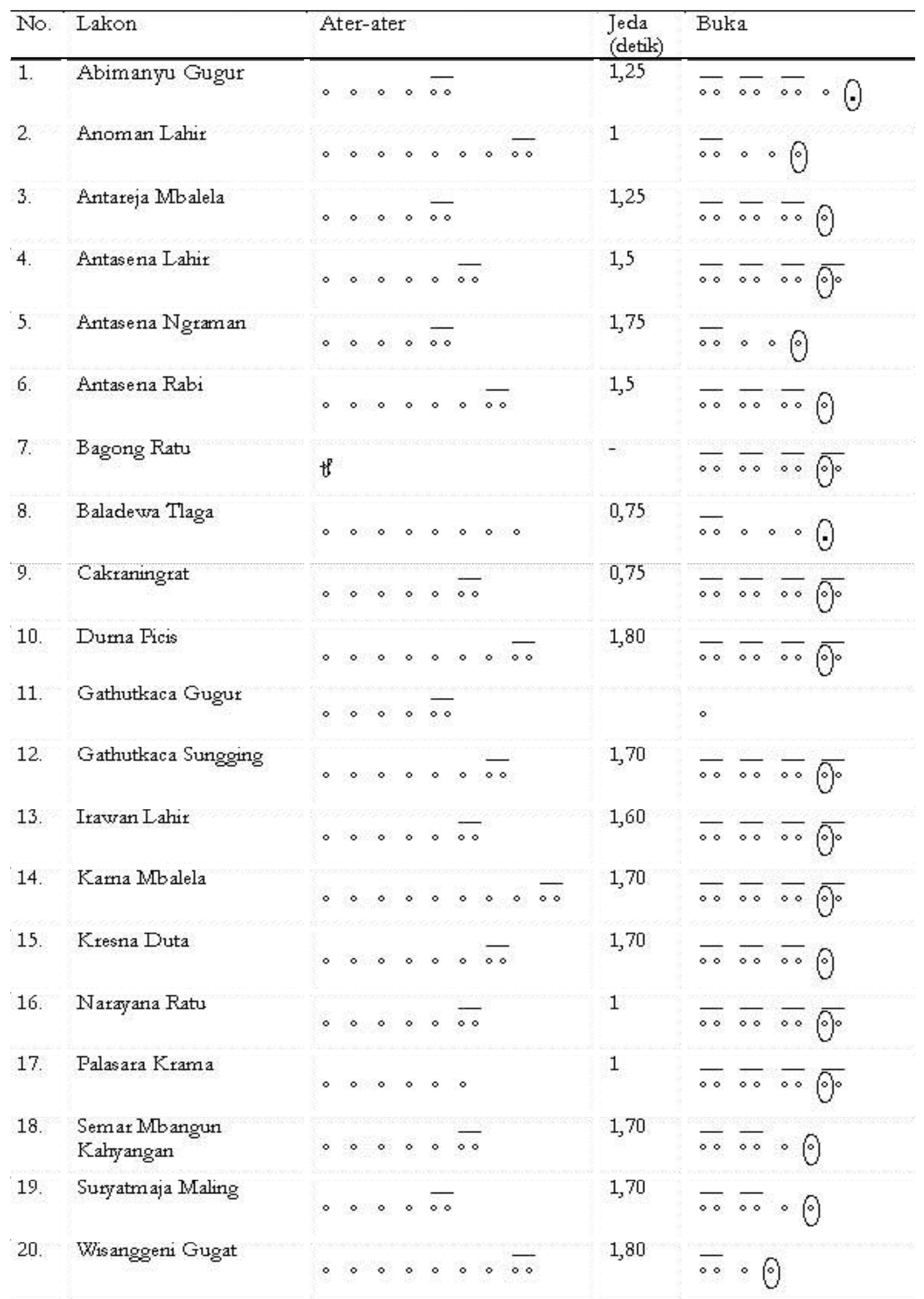

Sumber: Pengamatan terhadap 20 pertunjukan wayang (Putra, dkk. 2013) 
siap semua, keprakan hanya sebentar. Sebaliknya kalau menurut dalang suasana pengrawit belum kondusif keprakan neteg sampai 8 kali.

Antara ater-ater dan buka terdapat jeda waktu beberapa detik dimaksudkan untuk memberi waktu kepada para pengrawit bahwa pertunjukan akan dimulai. Waktu jeda antara ater-ater dengan buka juga bervariasi, antara 0,75 detik sampai 1,80 detik. Lamanya jeda waktu antara ater-ater dengan buka tergantung pada persepsi dalang akan kesiapan para pengrawitnya.

Pada bagian buka selain sebagai tanda juga sebagai penuntun tempo. Tempo karawitan akan mengikuti ketukan keprak yang diberikan oleh dalang. Dalang akan menghentikan keprakannya ketika tempo gending sudah stabil atau sudah sesuai dengan yang dikehendaki dalang. Itulah sebabnya jumlah keprakan antara pertunjukan satu dengan yang lain bisa berfariasi (Tabel 5).

\section{Keprakan sebagai Pembentuk Rasa}

Fungsi keprakan sebagai pembentuk rasa pertunjukan terlihat ketika keprakan ini digunakan untuk mengiringi gerakan wayang, mengiringi narasi kandha, dan mengiringi lagu atau sulukan. Keprakan dapat digunakan untuk membangun berbagai rasa (Tabel 6). Untuk membangkitkan rasa susah, sangat penting, atau mengagetkan, dalang memberi keprakan neteg satu kali. Tentu saja tidak hanya keprakan yang berperan membentuk rasa, tetapi didukung oleh unsur karawitan yang lain. Misalnya untuk menciptakan rasa yang sedih, setelah dalang membunyikan keprakan neteg satu kali, penggender segera ninthing atau menuntun dalang untuk melagukan suluk tlutur diikuti oleh bunyi rebab dan gambang, maka rasa yang terbangun adalah sedih (Benamou, 2010).

Untuk membangkitkan rasa marah, dalang memberi keprakan geter diikuti dengan suluk $a d a-a d a$ yang diiringi oleh instrumen gender, kempul dan gong. Demikian juga untuk membangkitkan suasana yang seolah-olah gaduh, rusak, dan tidak teratur, misalnya pada saat menarasikan keadaan gara-gara diikuti dengan keprakan geter. Seandainya dalang saat menarasikan suasana gara-gara tidak diikuti dengan keprakan geter, suasana tidak akan terbangun.

Tabel 4. Variasi keprakan ater-ater untuk memulai pertunjukan

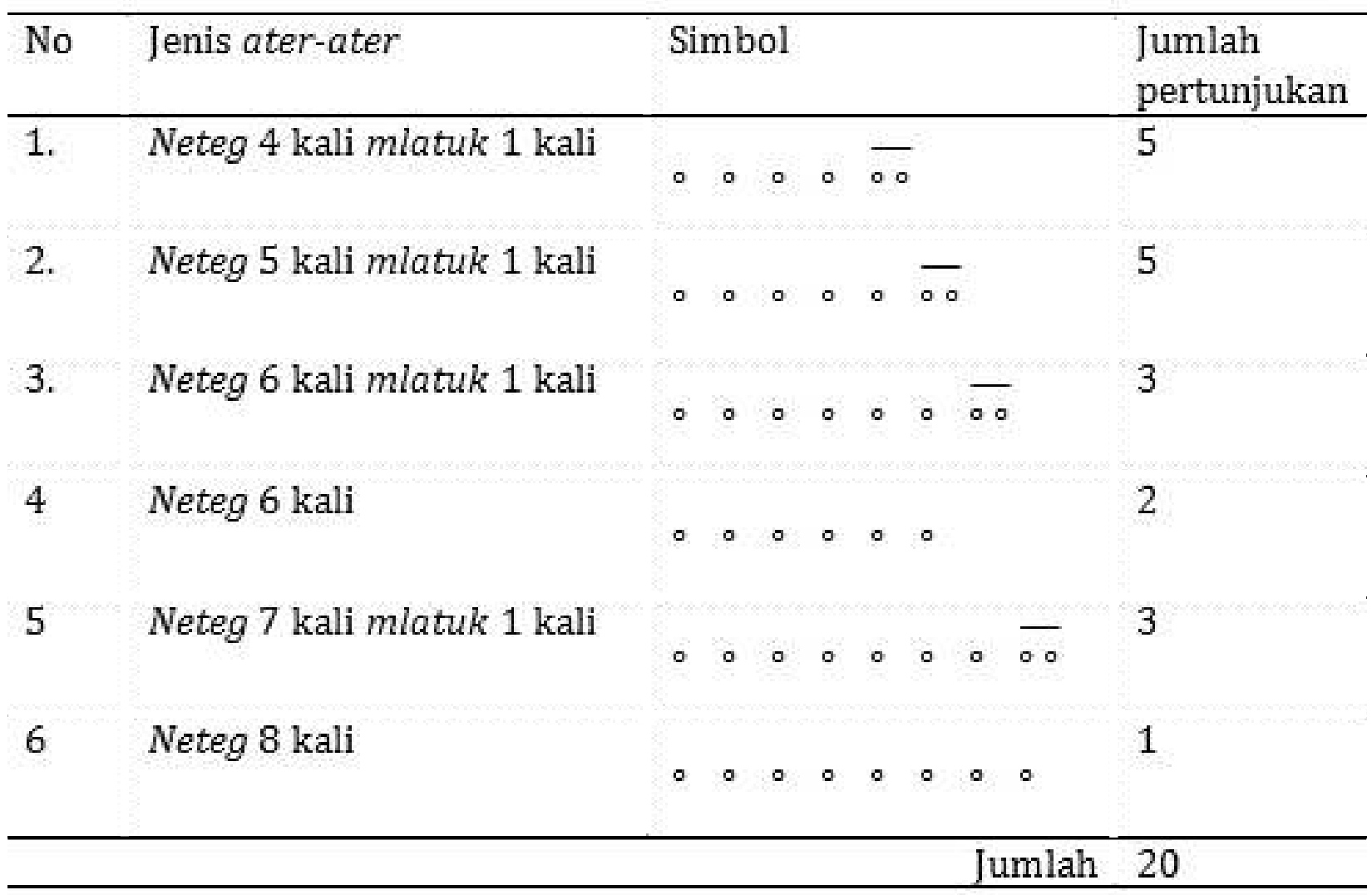

Sumber: Pengamatan terhadap 20 pertunjukan wayang (Putra, dkk. 2013) 
Tabel 5. Variasi keprakan buka pada Gending Karawitan

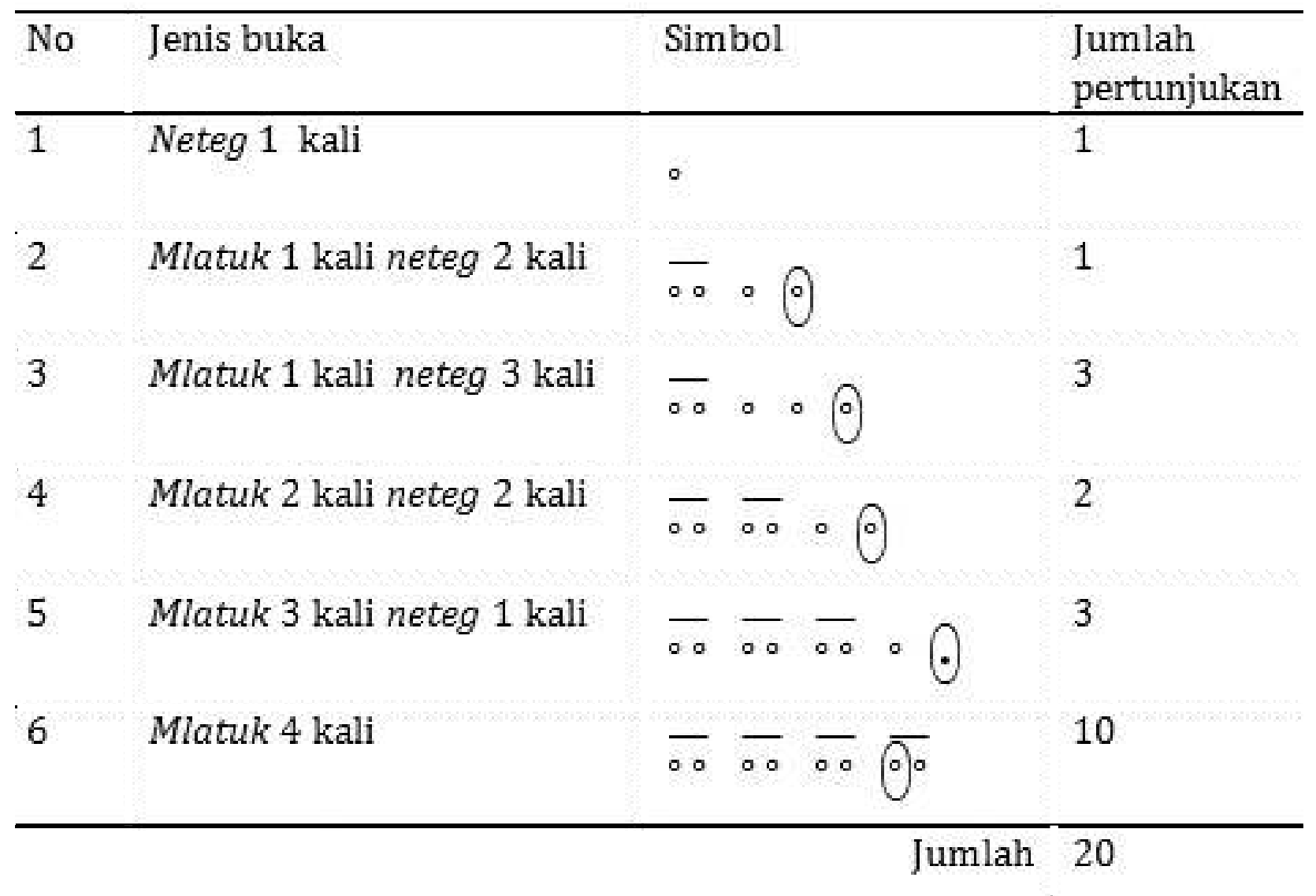

Sumber: Pengamatan terhadap 20 pertunjukan wayang (Putra, dkk. 2013)

Gerak wayang agar terlihat hidup juga diikuti oleh keprakan yang dihasilkan oleh cempala kaki dan kecrek. Untuk menghidupkan wayang biasanya digunakan keprakan $n d u d u k$. Tentu saja keprakan ini juga didukung oleh bunyi kendang yang dapat menguatkan rasa.

\section{Keprakan pada Gending Wayang}

Telah disinggung pada bagian depan bahwa dalam pertunjukan wayang ada beberapa jenis gending yang biasa digunakan untuk mendukung pertunjukan wayang yaitu Ayak-ayak, Playon, Sampak, Ketawang, Ladrang, dan Gendhing Candra.
Setiap jenis gending mempunyai cara keprakan yang berbeda baik saat memulai (buka), sirep (rep), maju, ataupun untuk memberhentikan (nyuwuk).

\section{Gending Ayak-ayak}

Ada beberapa jenis gending Ayak-ayak, antara lain Ayak-ayak Lasem, Ayak-ayak Sanga, Ayak-ayak Manyura, Ayak-ayak Tlutur, dan Ayak-ayak Pamungkas. Dalam pertunjukan wayang gaya Yogyakarta umumnya Ayakayak hanya dipentaskan satu kali dalam setiap patetnya.

Berdasarkan pengamatan terhadap gending Ayak-ayak pada 20 pertunjukan wayang, keprakan memiliki tipe yang hampir sama (Pola 1).

Tabel 6. Keprakan sebagai pembentuk rasa

\begin{tabular}{cll}
\hline No. & \multicolumn{1}{c}{ Jenis Keprakan } & \multicolumn{1}{c}{ Fungsi } \\
\hline 1. & Geter & Menciptakan suasana tegang, marah \\
2. & Neteg 1 kali diikuti sluluk tutur & Menciptakan suasana sedih \\
3. & Neteg 1 kali diikuti sluluk mambeng & Menciptakan suasana sangat penting \\
4. & Mlatuk 1 kali diikuti neteg 1 kali pada dialog wayang & Menciptakan suasana biasa \\
\hline
\end{tabular}




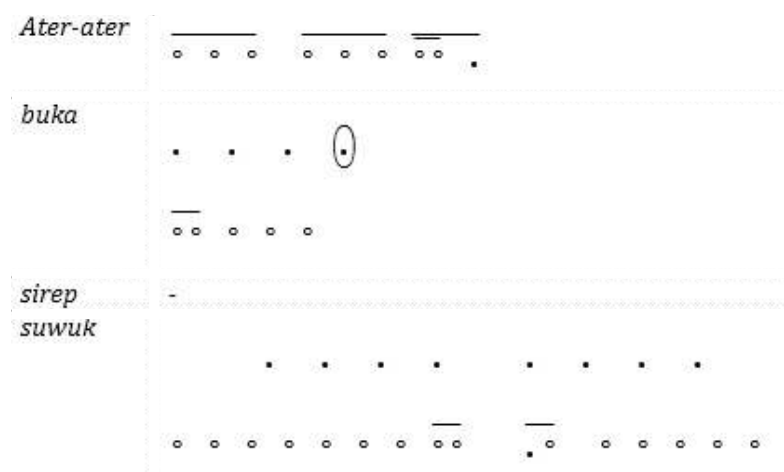

Pola 1. Keprakan pada gending ayak-ayak

Untuk memulai gending Ayak-ayak dapat dimulai dengan aba-aba berupa ater-ater neteg beberapa kali diikuti mlatuk satu kali, setelah itu mlatuk satu kali diikuti Mbanyu tumetes. Fungsi

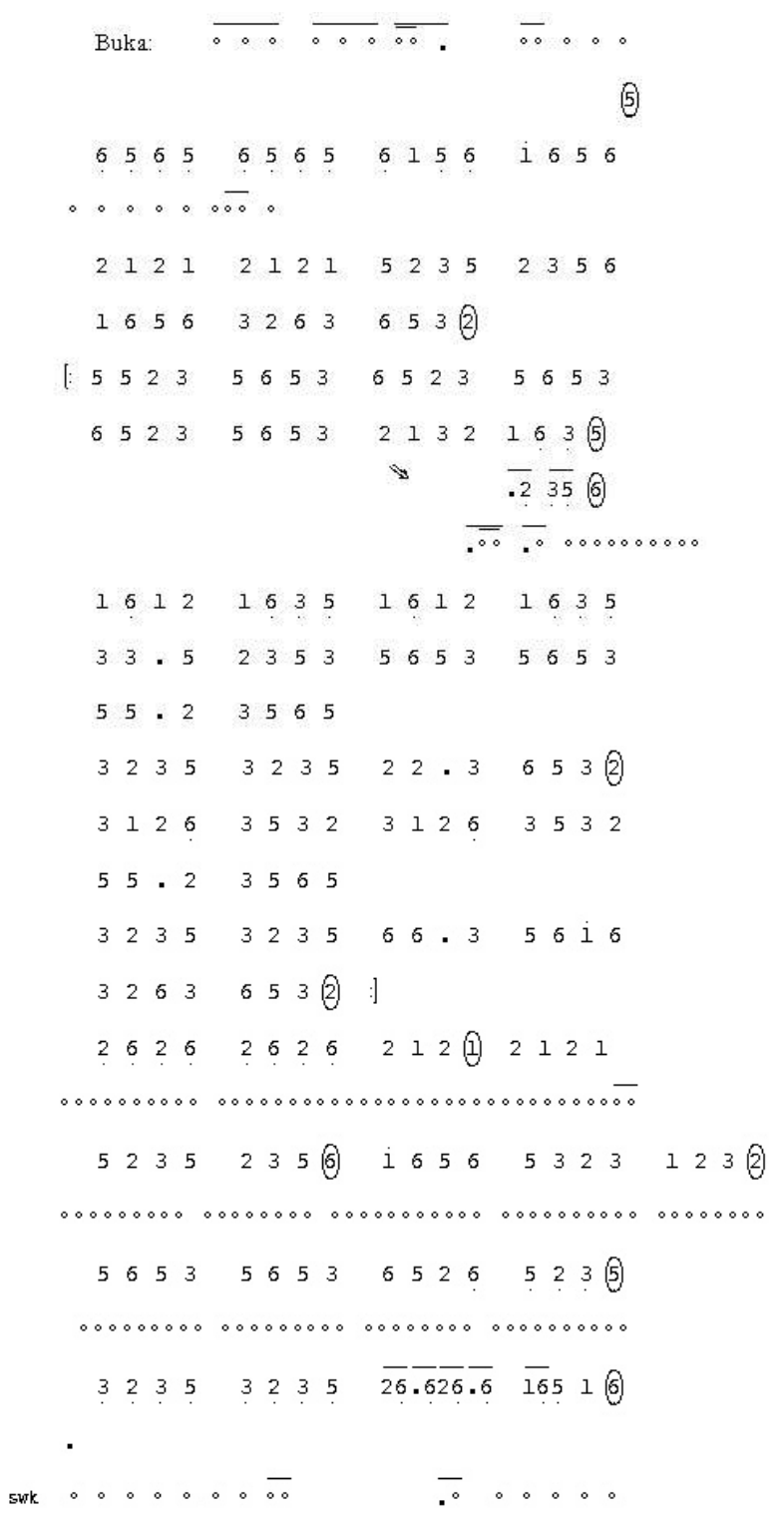

Keprakan gending Ayak-ayak Lasem pada pementasan lakon Antasena Lair keprakan Mbanyu tumetes dimaksudkan untuk menuntun tempo yang dikehendaki dalang.

Jarang sekali dalam pertunjukan wayang Gaya Yogyakarta gending Ayak-ayak dibuat rep. Untuk menghentikan atau nyuwuk gending Ayak-ayak dilakukan dengan keprakan mbanyu tumetes beberapa kali diikuti mlatuk satu kali tepat pada hitungan keempat pada gatra sebelum terakhir diikuti dengan neteg satu kali pada hitungan pertama gatra terakhir kemudian diikuti keprakan Mbanyu tumetes sampai sesaat setelah gong.

\section{Gending Playon}

Gending Playon merupakan gending yang paling sering digunakan dalam mendukung pertunjukan wayang. Untuk memulai gending jenis ini ditandai dengan ater-ater berupa keprakan geter. Setelah geter diikuti dengan keprakan mlatuk satu kali neteg satu kali diikuti dengan geter sampai tempo sesuai dengan yang dikehendaki dalang.

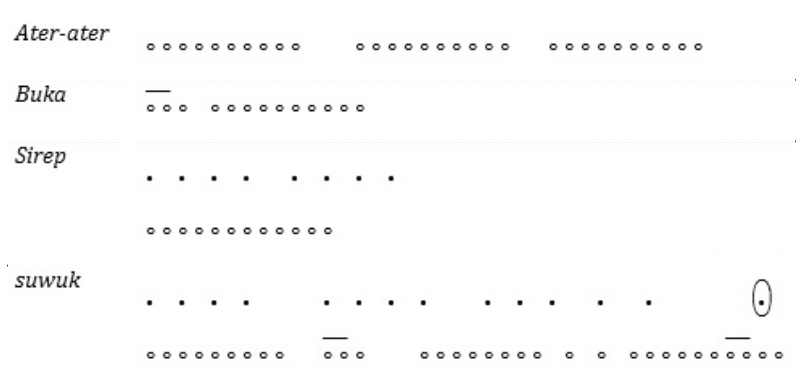

Pola 2. Keprakan pada gending playon

Gending Playon sangat fleksibel, dalam artian dapat di-sirep (rep) setiap saat dan disuwuk setiap saat. Untuk membuat rep gending ini dilakukan dengan keprakan Mbanyu tumetes dengan tempo yang semakin cepat (ngangseg) lalu keprakan berhenti, maka pengendang akan membuat tanda rep. Untuk mengembalikan atau membuat udhar digunakan keprakan neteg satu kali. Untuk menghentikan atau nyuwuk gending ini dilakukan dengan keprakan geter lalu jeda dilanjutkan geter lagi diikuti mlatuk sekali. maka pengendang akan membuatkan pola kendang untuk berhenti.

Ada dua kemungkinan suwuk gending Playon, yaitu suwuk antal dan suwuk seseg. Apabila menghendaki suwuk antal, maka setelah 
gong diikuti keprakan mbanyu tumetes, tetapi kalau suwuk seseg diikuti dengan keprakan geter.

$$
\overline{p l} b \cdot(5)
$$

65655655235616656203532212 (1)

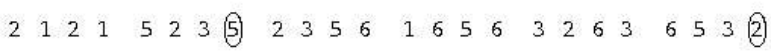

$\left[\begin{array}{lllllllllllllllllllll}5 & 6 & 5 & 3 & 5 & 6 & 5 & 3 & 6 & 5 & 2 & 6 & 5 & 2 & 3(5) & 1 & 2 & 3 & 2 & 6 & 5\end{array} 2\right.$ (3)

$535352351653213(2) 1632356$ (5)

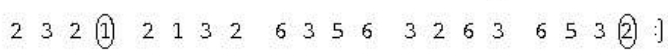

00000000.000000000

srik

$$
\begin{array}{lllll}
1 & 1 & 3 & 2 & 1
\end{array}
$$

Keprakan gending Playon Lasem untuk buka dan suwuk antal pada pementasan lakon Antasena Lair.

\section{Gending Sampak}

Dalam pertunjukan wayang tradisi Yogyakarta ada dua gending Sampak yang sering dipentaskan dalam pertunjukan wayang yaitu Sampak Sanga dan Sampak Manyura. Untuk memulai gending ini didahului dengan ater-ater berupa keprakan geter diikuti dengan keprakan neteg beberapa kali. Ketika mendengar keprakan neteg beberapa kali, pengendang akan membuat pola kendangan dengan bunyi kendang dlang maka instrumen yang lain akan mengikuti untuk menyajikan gending Sampak.

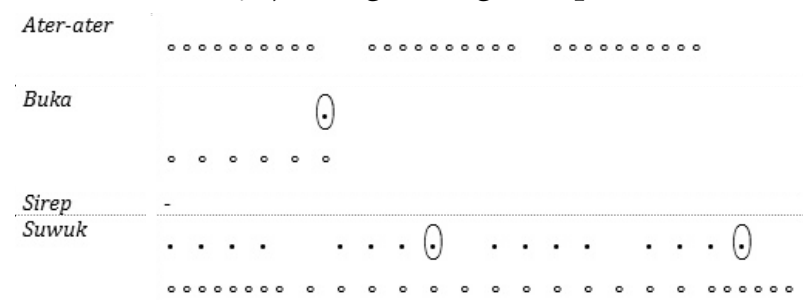

Pola 3. Keprakan pada gending sampak

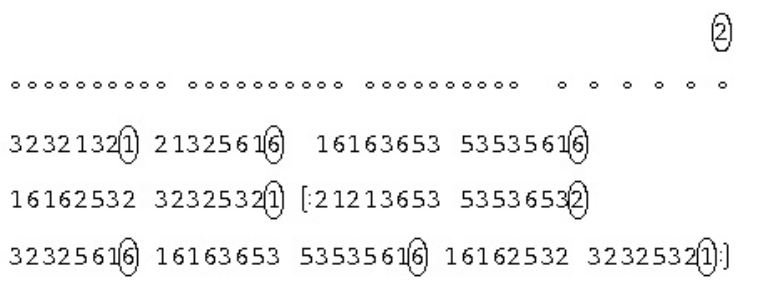

swk 3123

Keprakan gending Sampak Manyura dalam pertunjukan Ki Hadi Sugito pada lakon Baladewa Tlaga.
Untuk menghentikan atau nyuwuk gending Sampak dilakukan dengan cara keprakan geter dilanjutkan mbanyu tumes lalu geter lagi.

\section{Gending Ketawang}

Gending jenis ketawang jarang digunakan untuk mengiringi pertunjukan wayang. Hanya ada beberapa gending antara lain Ketawang Subakastawa, Ibu Pertiwi, dan Puspawarna yang kadang-kadang digunakan. Gending ini biasanya digunakan untuk mengiringi tokoh wayang yang sedang berjalan di tengah hutan.

Untuk memulai gending ini setelah dalang memberi sasmita gending yang dikehendaki dilanjutkan dengan ater-ater berupa keprakan mlatuk sekali neteg sekali. Setelah mendengar keprakan tersebut perebab akan memulai buka dan pada ketukan ke dua belas dalang memberi keprakan neteg satu kali.

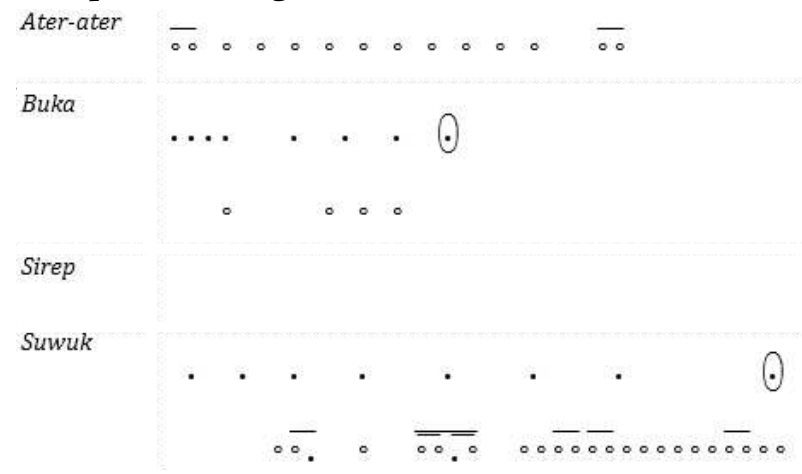

Pola 4. Keprakan pada gending ketawang

Untuk nyuwuk gending ini digunakan keprakan mlatuk beberapa kali dimulai pada ketukan kesepuluh kemudian mlatuk beberapa kali diikuti dengan banyu tumetes dengan tempo yang semakin lambat, diakhiri dengan mlatuk sekali neteg sekali sampai gong dibunyikan. Setelah gong diikuti neteg satu kali.

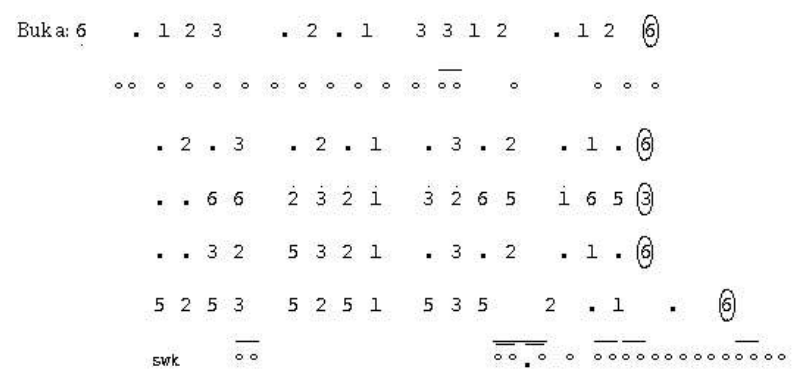

Keprakan buka dan suwuk pada gending Ketawang Puspawarna Slendro Manyura pada pementasan Ki Hadi Sugito. 


\section{Gending Ladrang}

Ada banyak gending ladrang yang digunakan untuk mendukung pertunjukan wayang. Antara lain Ladrang Pangkur, Ladrang Tebu Sauyun, Ladrang Clunthang, dan Ladrang Maskumambang (Prasetya, 2013: 59).

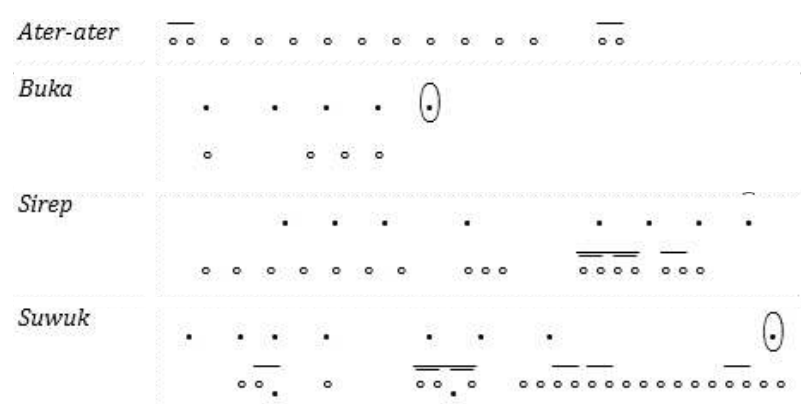

Pola 5. Keprakan pada gending ladrang untuk buka, sirep, dan suwuk gropak

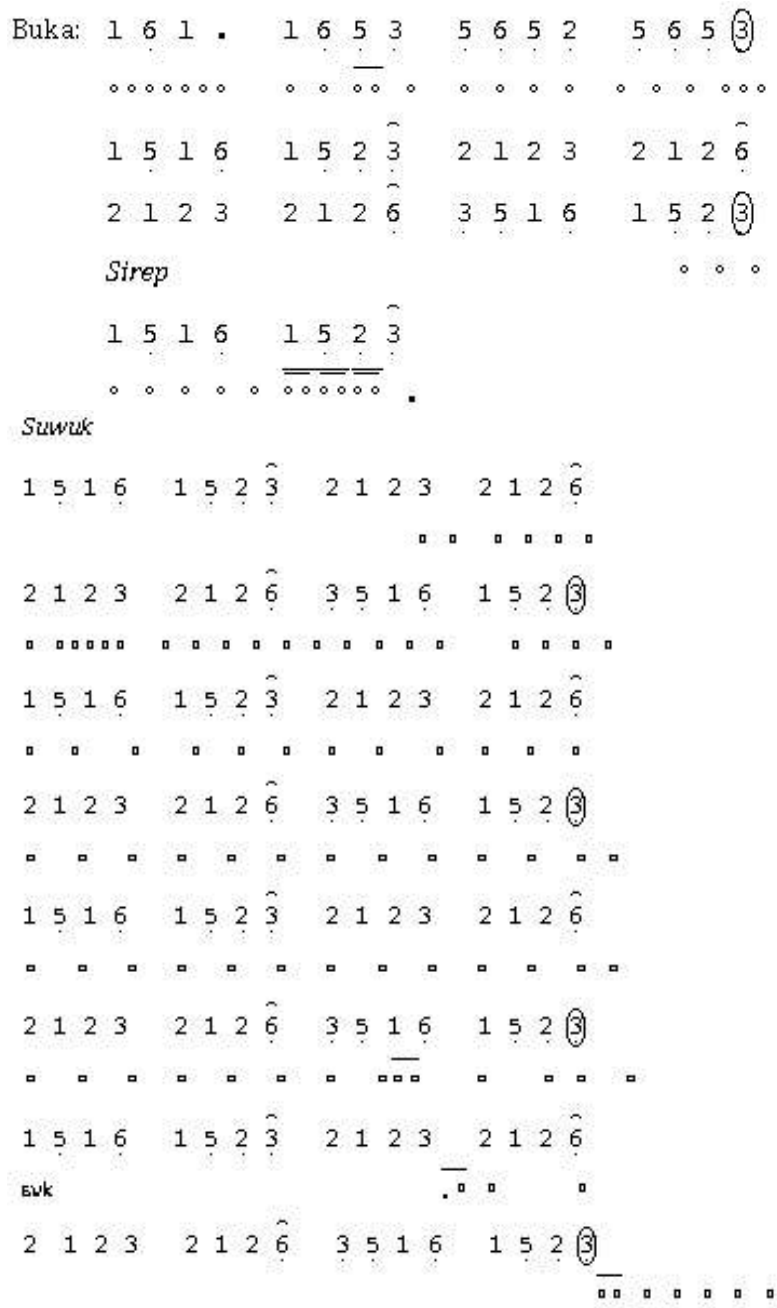

Keprakan pada gending Ladrang Maskumambang Slendro Manyura pada Jejer IV untuk mengiringi jejer wadya sabrang raksasa dengan suwuk gropak pada pementasan lakon Gathutkaca Sungging
Pada pertunjukan wayang, selesai atau suwuk-nya gending tergantung pada tokoh wayang yang dipergelarkan. Bila tokoh wayang yang dipergelarkan adalah tokoh raksasa atau wayang gagahan, gending diakhiri dengan tempo cepat atau suwuk gropak. Namun jika tokoh wayang yang didukung adalah wayang halus, wanita, atau wayang dalam suasana susah, tenang, dan biasa, gending diakhiri dengan suwuk tempo lambat atau antal yang diikuti dengan suluk lagon.

Pada bagian buka, gatra I dan II merupakan ater-ater, sedangkan gatra III dan IV keprak menuntun irama pada kendang agar tempo tetap pada irama I. Sampai keprak tidak dimainkan tempo berubah menjadi irama II.

Untuk memberi tanda sirep, keprak dimulai dari gatra gong menggunakan keprakan banyu tumetes sampai gatra kenong pertama. Untuk nyuwuk gropak, pada kempul pertama keprak mendorong tempo agar beralih ke irama I. Peralihan irama ini merupakan tanda suwuk gropak.

\section{Gending Candra}

Ada beberapa gending Candra yang biasa digunakan untuk mendukung pertunjukan wayang antara lain Gendhing Krawitan, Gendhing Genes, dan Gendhing Runtut Slendro Sanga.

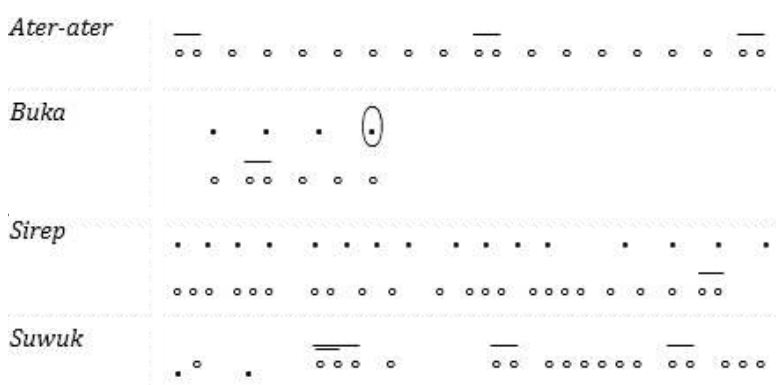

Pola 6. Keprakan pada gending candra

\section{Keprakan Gending Candra}

Gending Runtut pada contoh berikut biasanya digunakan untuk mengiringi pertunjukan pada Jejer IV. Untuk memulai repertoar ini diawali dengan ater-ater mlatuk sekali neteg sekali agar perebab memulai buka. Setelah rebab mulai repertoar, pada ketukan ke empat belas diberi keprakan mlatuk untuk menegaskan rasa gending. 
Apabila akan sirep, dalang memberi aterater berupa keprakan banyu tumetes mulai dari satu gatra menjelang gong sampai gatra ketiga kenong pertama. Keprakan dilanjutkan mlatuk mendekati kenong pertama, sehingga saat kenong, irama sudah sirep.

Pada saat sirep, gending berpindah ke bagian dhawah. Bada bagian ini dalang memberi narasi janturan. Setelah janturan selesai, dalang memberi keprakan neteg satu kali untuk memberi tahu agar gamelan menjadi gesang atau udhar. Untuk menghentikan repertoar atau nyuwuk, dilakukan dengan cara memberi keprakan neteg sesaat setelah gatra kedua. Setelah itu dilanjutkan keprakan cengkok suwuk berupa mlatuk neteg pada ketukan ke sebelas dan ke tiga belas kenong terakhir dilanjutkan banyu tumetes dengan tempo semakin pelan diakhiri dengan mlatuk lagi untuk memberi tanda gong. Penabuh gong akan menabuh gong setelah mendengar keprakan mlatuk ini. Setelah gong dilanjutkan neteg tiga kali.

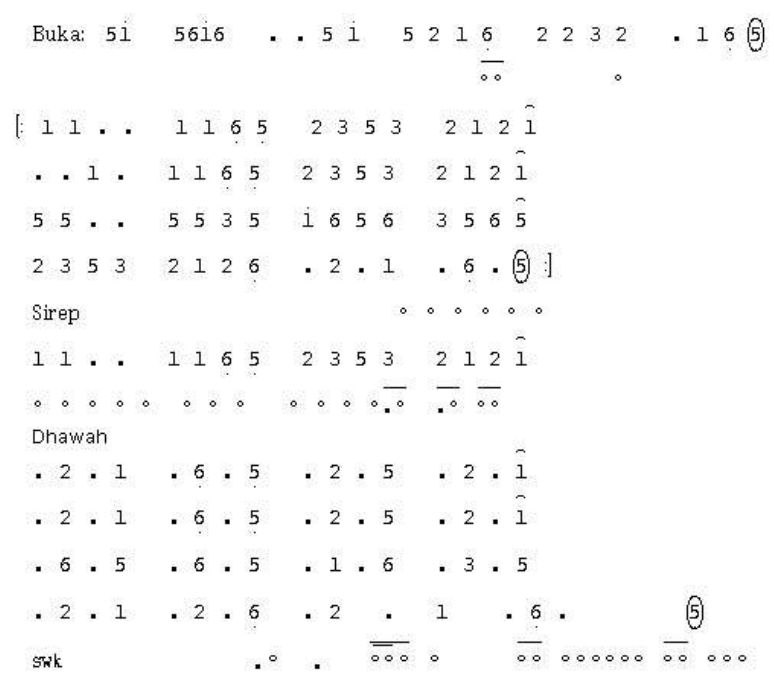

Keprakan pada gending Runtut Slendro Sanga untuk mengiringi Jejer IV tokoh bambangan pada lakon Gathutkaca Sungging

\section{Penutup}

Berdasarkan penelitian keprakan pada dua puluh pertunjukan wayang dapat disimpulkan bahwa pola permainan keprakan selain merupakan penunjang suasana adegan pada pertunjukan wayang juga berfungsi sebagai tanda atau aba-aba dalang pada seluruh pengrawit. Pada dasarnya hanya terdapat dua bentuk dasar keprakan yaitu neteg dan mlatuk. Dari dua pola ini berkembang pola permainan lainnya seperti, mbanyu tumetes, geter, nduduk, nyisir, dan nyeceg. Pola-pola ini dapat ditemukan pada setiap pertunjukan wayang. Sehingga dapat disimpulkan keprakan memiliki beberapa fungsi antara lain sebagai: (1) tanda dimulainya pertunjukan; (2) Aba-aba terhadap pengrawit untuk memainkan suatu gending, baik ketika gendhing akan dimulai, sirep, seseg, dan suwuk; penanda berakhirnya janturan, dan sasmita sulukan; (3) Pembentuk rasa pertunjukan. Tiap jenis keprakan memiliki fungsi yang berbeda dan semuanya menghasilkan estetika pedalangan gaya Yogyakarta.

Penelitian ini mampu menemukan pola-pola keprakan pada berbagai jenis gending dan berbagai jenis suasana dalam pertunjukan wayang yang menghasilkan estetika pedalangan. Dengan cara seperti ini estetika pedalangan dapat dipelajari oleh siapapun yang mendalami pertunjukan wayang karena hingga saat ini belum ada tulisan yang membahas hal ini.

\section{Ucapan Terima Kasih}

Rasa terima kasih kami ucapkan kepada Direktur DP2M Dikti yang telah memberi dana hibah bersaing selama dua tahun untuk penelitian ini. Terima kasih juga disampaikan kepada mitra bebestari Resital Jurnal Seni Pertunjukan yang telah memberi masukan untuk perbaikan artikel ini.

\section{Kepustakaan}

Becker, Judith. 1979. "Time and Tune in Java" dalam A. L Becker dan Aram A. Yengoyan (eds), The Imagination of Reality, New Jersey: 1979. pp. 197 - 210 . 2004. Deep Listeners: Music, Emotion, and Trenching. Bloomington: Indiana University Press.

Benamou, Marc. 2010. Rasa: Affect and Intuition Javanese Musical Aesthetics. New York: Oxford University Press.

Brinner, Benjamin. 2008. Music in Central Java. 
New York: Oxford University Press Mudjanattistomo, RM., dkk. 1977. Pedhalangan Ngayogyakarta. Yogyakarta: Habirandha.

Prasetya, Hanggar Budi. 2011. Ki Hadi Sugito:

Guru Yang Tidak Menggurui. Yogyakarta: BP ISI .2013. "Mleset dan Nggandhul dalam Karawitan Pedalangan Gaya Yogyakarta: Tinjauan Budaya, Karawitanologi, dan Fisika Bunyi” [Disertasi]. Yogyakarta: Prodi Pengkajian Seni Pertunjukan dan Seni Rupa, Sekolah Pascasarjana Universitas Gadjah Mada Yogyakarta.

Putro, Ign. Nurtanto., Hanggar B. Prasetya, dan Sunyata. 2013. "Keprakan dan Dhodhogan Hadisugitan dalam Membentuk Estetika Pedalangan Gaya Yogyakarta" [Laporan Penelitian] Hibah Bersaing. Jakarta: DP2M Dikti

Soetarno, Sunardi, dan Sudarsono. 2006. Estetika Pedalangan. Surakarta: ISI Surakarta

Hadiprayitno, Kasidi. 2004. Teori Estetika Untuk Pedalangan. Yogyakarta: BP ISI.

Weis, Sarah. 2003. "Embodiment and Aesthetics in Javanese Performance" dalam Asian Music, Spring/Summer 2003, pp. 29-45

Audio

Sugito, Hadi. 2006. Lakon Abimanyu Gugur. (Pita Kaset). Dahlia 2006. Lakon Anoman Lahir. (Pita Kaset). Dahlia 2006. Lakon Antareja Mbalela. (Pita Kaset). Fajar
2006. Lakon Antasena Lahir. (Pita

Kaset). Dahlia 2007. Lakon Antasena Ngraman. (Pita

Kaset). Kusuma Recording 2007. Lakon Antasena Rabi. (Pita

Kaset). Dahlia 2007. Lakon Bagong Ratu. (Pita

Kaset). Fajar 2007. Lakon Baladewa Tlaga. (Pita

Kaset). Dahlia 2007. Lakon Cakraningrat. (Pita Kaset). Fajar 2007. Lakon Durna Picis. (Pita Kaset).

Dahlia

Kaset). Fajar 2007. Lakon Gathutkaca Sungging.

(Pita Kaset). Fajar . 2008. Lakon Irawan Lahir. (Pita

Kaset). Dahlia . 2008. Lakon Karna Mbalela. (Pita

Kaset). Dahlia . 2008. Lakon Kresna Duta. (Pita

Kaset). Dahlia 2008. Lakon Narayana Ratu. (Pita

Kaset). Dahlia 2008. Lakon Palasara Krama. (Pita

Kaset). Dahlia - 2008. Lakon Semar Mbangun Kahyangan. (Pita Kaset). Kusuma Recording 2008. Lakon Suryatmaja Maling. (Pita Kaset). Dahlia 2008. Lakon Wisanggeni Gugat. (Pita Kaset). Kusuma Recording 